\title{
新 マリン系殺鼠剂に関する研究
}

第 1 報 実験用ネズミ類についての基礎的研究

\author{
北 川晴 雄 ${ }^{1} \cdot$ 岩城利一郎 ${ }^{1}$.斎 藤 晴 夫 ${ }^{1}$

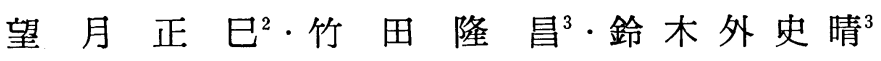 \\ 敦 賀 正 教 ${ }^{3}$. 稲 塚 直 数 ${ }^{3}$.小 川 浄 $^{3}$
}

緒

$\overline{\overline{\bar{~}}}$

殺鼠郕は公衆衛生から農林業にわたる広い範囲でネズ そ類の駆除に使用されている。従来用いられているのは 炭酸バリウム, 亜砣酸, 亜砒酸カルシウム, 黄リン, リ ン化亜鉛, モノフルオール酢酸ソーダ, 海葱, ストリキ ニーネ，ピリジン，尿素あるいはクマリン誘導体などで あり，何れも急性あるいは慢性中毒を起こさせ，ネズミ を死に至らしめる。しかしその実用面において一長一短 があり，満足すべき殺鼠効果のあるものは少ない。たと えば殺鼠力が強い化合物はネズミ類にたいして著るしい 忌避作用を示したり，家畜類にたいして危害を及ぼすこ とが多い。また慢性中毒作用を期待する場合は長期連続 投与の困難性などが問題となる。

著者らのうち，北川および岩城（1958 a , b ) はクマ リン誘導体 93 種類について, シロネズミにたいする体 温降下作用を検討し, coumarin-3-carboxylic acid, 6-coumarinylamine coumarin-3-carboxylate など が強力な体温降下作用および毒性をもつとともに，溶血 作用や血液凝固阻止作用なども比較的強いことを見いだ しだ。そこでこれらクマリン誘導体を殺鼠戍として利用 するため，毒性，一般薬理作用およびシロネズミ，ハッ カネズミなど実験用ネズる類にたいする殺鼠効果, 忌避 性などを検討し， coumarin-3-carboxylic acid およ びその 6-coumarinylamine あるいはタリウム塩が強 い殺鼠効果をもつと同時に，家畜類にたいする危害がほ とんどないことを認めたので報告する。なお供試した主 たるクマリン誘導体は第 1 表に掲げるごとくであり 4 , また対照化合物としてワルフォリンを供試した。
実 験 の 部

I. 生物学的試験

毒性試験：ハツカネズミに 経口的に 投与した場合の 50\% 致死量および確実致死量は第 1 表に示すごとくで ある。ワルファリンが慢性中毒作用を特長とする殺鼠刘 であり急性毒性が低いのに反し, coumarin-3-carboxylic acid, ethyl coumarin-3-carboxylate, 6-coumarinylamine coumarin-3-carboxylate, thallium coumarin-3-carboxylate などは強力な急性中毒作用 をもつ。その死亡徵候は臟器各所の出血, とくに腸管の 弛緩と出血, 胸腔湓血, 肺充血などである。

一方イヌおよびネコにたいする coumarin-3-carboxylic acid, 6-coumarinylamine coumarin-3carboxylate, thallium coumarin-3-carboxylate $の$ 毒性は，それぞれ $100 \mathrm{mg} / \mathrm{kg}$ を食餌に混入投与した場 合に,イヌ、ネコとも 30〜60 分後に欧吐を起こした。 さらに coumarin-3-carboxylic acid および 6-coumarinylamine coumarin-3-carboxylate では 1〜2 時間後にけいれん発作を起こし，その後虚脱状態が続く が，4〜5 時間後には正常に復した。概して欧吐が早い ほど回復時間も早いようであった。

つぎに 6-coumarinylamine coumarin-3-carboxylate をイヌ（スピッツ雄および雑種雌）に $100 \mathrm{mg} / \mathrm{kg}$ の割合で 30 日間食慨に混入投与し，その間の体重の変 化と外見的彺候を記録した。結果法第 1 図のように，2 頭とも第 1 日目に欧吐をもよおし，その後も $3 ， 4$ 回の 欧吐が認められた。2 日目以後は毒物混入飼料を忌避す るようになり，体重は減少した。しかしながら 30 日間

1 富山大学薬学部

2 富山県農業試験場

3 富士薬品工業株式会社

4 本研究に供試した化合物については特許申請中である。 (1963 年 2 月 7 日受領) 
第 1 表 供試クマリン誘導体とその $50 \%$ 致死量扰よび確実致死量

\begin{tabular}{l|c|c}
\multicolumn{1}{c|}{ 合 } & $\begin{array}{c}\text { 化 } \\
\begin{array}{c}\text { 名確実致死量 } \\
(\mathrm{mg} / \mathrm{kg})\end{array}\end{array}$ & $50 \%$ 致死量 $(\mathrm{mg} / \mathrm{kg})$ \\
\hline Coumarin-3-carboxylic acid & $180 \sim 200$ & $88.4(68.1 \sim 114.5)$ \\
Ethyl coumarin-3-carboxylate & 180 & $103.5(91.7 \sim 117.1)$ \\
Aniline coumarin-3-carboxylate & 260 & $148.0(126.8 \sim 172.7)$ \\
6-Coumarinylamine coumarin-3-carboxylate & 210 & $142.0(127.9 \sim 157.7)$ \\
4-Methyl-7-coumarinylamine coumarin-3-carboxylate & 210 & \\
6-Aminocoumarin & 750 & $475.5(445.5 \sim 505.4)$ \\
6-Aminocoumarin hydrochloride & 900 & $662.3(457.2 \sim 960.0)$ \\
Tl coumarin-3-carboxylate & 190 & \\
Ba coumarin-3-carboxylate & 190 & \\
Pb coumarin-3-carboxylate & 240 & \\
Cu coumarin-3-carboxylate & 340 & \\
Hg coumarin-3-carboxylate & 240 & \\
Na coumarin-3-carboxylate & 200 & $79.0(40.2 \sim 126.4)$ \\
Poly Na coumarin-3-carboxylate & 210 & \\
K coumarin-3-carboxylate & 200 & \\
Coumarin-3-carboxychloride & $1200 \sim 1728$ & $845.0(776.0 \sim 920.2)$ \\
Warfarin(3- $\alpha$-acetonylbenzyl-4-hydroxycoumarin) &
\end{tabular}
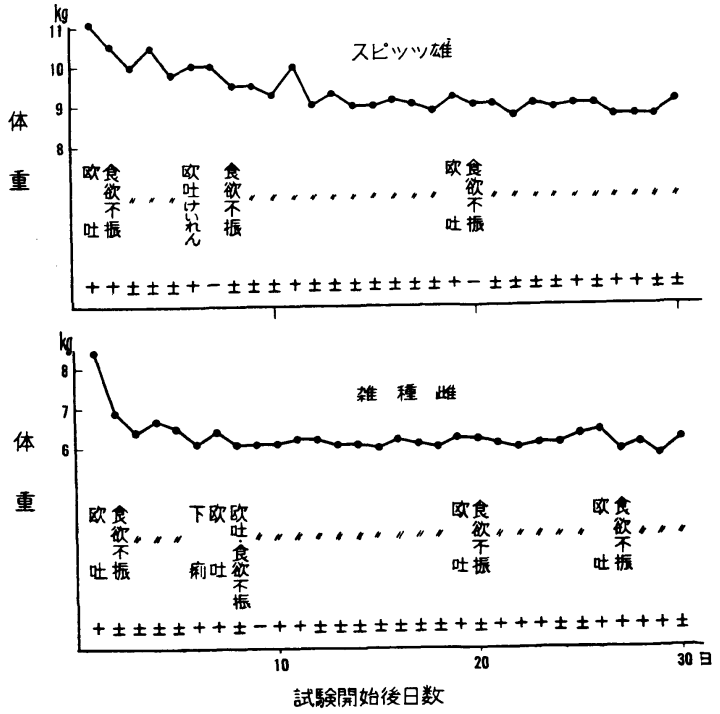

第 1 図 イヌに経口投与した 6-coumarinylamine coumarin-3-carboxylate の影響（投与 量：100 mg/ kg/日）

+ : 完全攝取, \pm : 大部分捸取

- : 半量摂取

連続投与後においても，2頭とも外観的には正常であっ た。屠殺解剖して内臓を肉眼的に調べたところ，雄イヌ では全く正常であったが，雌イヌでは脾臓がやや肥大黒 変し, 両肺に灰白色の部分が認められた。なおネコにつ いても同様の実験を試みたが，投与 2 日目以後は毒物混
第 2 表 ハツカネズミに経口断続投与した thallium coumarin-3-carboxylate の影響 + ：投与, - : 無投与

\begin{tabular}{|c|c|c|c|c|c|c|c|}
\hline & 区 調查日 & $\begin{array}{l}\text { 第 } 1 \\
\text { 日目 }\end{array}$ & 2 & 3 & 4 & 5 & 計 \\
\hline 1 & $\begin{array}{l}\text { 投与の有無 } \\
\text { 死亡 数 }\end{array}$ & $\begin{array}{l}+ \\
0\end{array}$ & $\begin{array}{l}+ \\
0\end{array}$ & $\begin{array}{l}+ \\
2\end{array}$ & $\begin{array}{l}+ \\
2\end{array}$ & $\begin{array}{c}+ \\
1\end{array}$ & 5 \\
\hline 2 & $\begin{array}{l}\text { 投与の有無 } \\
\text { 死 亡 数 }\end{array}$ & $\begin{array}{l}+ \\
0\end{array}$ & $\overline{1}$ & $\begin{array}{l}+ \\
0\end{array}$ & $\begin{array}{l}+ \\
2\end{array}$ & $\begin{array}{l}+ \\
2\end{array}$ & 5 \\
\hline 3 & $\begin{array}{l}\text { 投与の有無 } \\
\text { 死亡 数 }\end{array}$ & $\begin{array}{l}+ \\
0\end{array}$ & $\begin{array}{l}+ \\
0\end{array}$ & 2 & $\stackrel{+}{3}$ & $\begin{array}{l}+ \\
0\end{array}$ & 5 \\
\hline 4 & $\begin{array}{l}\text { 投与の有無 } \\
\text { 死 亡 数 }\end{array}$ & $\begin{array}{l}+ \\
0\end{array}$ & $\begin{array}{l}+ \\
0\end{array}$ & + & $\frac{-}{3}$ & $\begin{array}{l}+ \\
0\end{array}$ & 5 \\
\hline 5 & $\begin{array}{l}\text { 投与の有無 } \\
\text { 死 亡 数 }\end{array}$ & $\stackrel{+}{0}$ & $\overline{0}$ & 2 & $\overline{1}$ & $\begin{array}{l}+ \\
2\end{array}$ & 5 \\
\hline
\end{tabular}

供試ネズミ数は各区とも 5 頭，体重は $13 \sim 18 \mathrm{~g}$ である。

入飼料を全く忌避したため，中止した。

供試化合物のうち 比較的蓄積 作用の強い thallium coumarin-3-carboxylate について，ハツカネズミに $50 \mathrm{mg} / \mathrm{kg} /$ 日 で断続経口投与して毒性を調べたところ, 第 2 表のように連続投与の場合と同様の殺鼠効果が認め られた。この点ワルファリンの作用とは異なる（三坂, 1944)。

体温にたいする作用: Coumarin-3-carboxylic acid, ethyl coumarin-3-carboxylate, aniline coumarin- 
3-carboxylate, 6-coumarinylamine coumarin-3carboxylate および 4-methyl-7-coumarinylamine coumarin-3-carboxylate をそれぞれ 3〜5 頭のシロ ネズミに皮下投与して，体温降下作用を調べた。その結 果第 3 表に示すようにいずれの化合物にも体温降下作用 が認められたが，とくに coumarin-3-carboxylic acid, ethyl coumarin-3-carboxylate および aniline coumarin-3-carboxylate では毒性が高く，ネズミは死亡 した。

Coumarin-3-carboxylic acid, 6-coumarinylamine coumarin-3-carboxylate, thallium coumarin-3 -carboxylate およびワルファリンを経口投与して調 べた結果，前 2 者に体温降下作用が認められた（第 4 表)。さらに殺鼠剤の冬季使用を考慮して低温時（14〜 $\left.16^{\circ} \mathrm{C}\right)$ に処理した場合にも，6-coumarinylamine coumarin-3-carboxylate に体温降下作用が認められた (第 5 表)。

血液にたいする作用：イエウサギの脱センイ素赤血球 生理食塩水浮游液を用い, 6-coumarinylamine coumarin-3-carboxylate の溶血作用をサポニンと比較し た結果，サポニンよりは弱いが，比較的顕著な溶血作用 を認めた（第 6 表）。また血液凝固阻止作用をみるため， イエウサギの血液を用い, Quick の一段法 (in vitro) でプロトロンビン時間を測定したところ，その血液凝固 阻止作用はシントローム“Geigy” にくらべて強かっ た（第 7 表）。

なお 6-coumarinylamine coumarin-3-carboxylate $10 \mathrm{mg} / \mathrm{kg}$ 経口投与したイエウサギの耳静脈か

第 3 表 シロネズミにたいする coumarin-3-carboxylic acid 誘導体の体温降下作用（皮下投与）

\begin{tabular}{|c|c|c|c|c|c|c|c|}
\hline 化 & $\begin{array}{l}\text { 供 試 } \\
\text { 動物数 }\end{array}$ & $\begin{array}{l}\text { 投与量 } \\
\mathrm{mg} / \mathrm{kg}\end{array}$ & $\begin{array}{c}\text { (a) } \\
\text { 正常体温 }\end{array}$ & \begin{tabular}{|c|} 
(b) \\
最低体温
\end{tabular} & $\begin{array}{c}\text { 到達時間 } \\
\text { (分) }\end{array}$ & $\begin{array}{l}(a-b) \\
\pm S . D .\end{array}$ & $\begin{array}{c}(a-b) \\
\text { の有意性 } \\
\text { の検定 }\end{array}$ \\
\hline \multirow{5}{*}{$\begin{array}{l}\text { Coumarin-3-carboxylic acid } \\
\text { Ethyl coumarin-3-carboxylate } \\
\text { Aniline coumarin-3-carboxylate } \\
\text { 6-Coumarinylamine coumarin- } \\
\text { 3-carboxylate } \\
\text { 4-Methyl-7-coumarinylamine } \\
\text { coumarin-3-carboxylate }\end{array}$} & 1 & 50 & - & - & 60 & 死亡 & - \\
\hline & 1 & 50 & - & 一 & 150 & 死亡 & - \\
\hline & 3 & 100 & 37.90 & - & & $2 / 3$ 死亡 & - \\
\hline & 3 & 100 & 37.87 & 35.80 & $90 \sim 180$ & $2.07 \pm 0.55$ & + \\
\hline & 5 & 50 & 38.04 & 36.04 & $40 \sim 105$ & $2.00 \pm 0.22$ & + \\
\hline
\end{tabular}

$(\mathrm{a}-\mathrm{b})$ の差の有意性の検定 $\left\{\begin{array}{l}+ \text { 差あり } \\ \text { 差なし }\end{array}(\mathrm{P}=0.05)\right.$

第 4 表 シロネズミにたいする coumarin-3-carboxylic acid 誘導体の高温時 に打ける体温降下作用（経口投与）(25～30 C )

\begin{tabular}{|c|c|c|c|c|c|c|c|}
\hline 物 & $\left|\begin{array}{lr}\text { 供 } & \text { 試 } \\
\text { 動物数 }\end{array}\right|$ & $\begin{array}{c}\text { 投与量 } \\
\mathrm{mg} / \mathrm{kg}\end{array}$ & $\begin{array}{c}(a) \\
\text { 正常体温 }\end{array}$ & $\begin{array}{c}\text { (b) } \\
\text { 最低体温 }\end{array}$ & $\begin{array}{c}\begin{array}{c}\text { 到達時間 } \\
\text { (分) }\end{array} \\
\end{array}$ & $\begin{array}{l}(a-b) \\
\pm S . D\end{array}$ & $\begin{array}{c}(a-b) \\
\text { の有意性 } \\
\text { の検定 }\end{array}$ \\
\hline \multirow{4}{*}{$\begin{array}{l}\text { Coumarin-3-carboxylic acid } \\
\text { 6-Coumarinylamine coumarin- } \\
\text { 3-carboxylate } \\
\text { Thallium coumarin-3-carboxy- } \\
\text { late } \\
\text { Warfarin }\end{array}$} & 3 & 50 & 37.85 & 35.60 & $30 \sim 60$ & $2.25 \pm 0.30$ & + \\
\hline & 3 & 50 & 38.21 & 37.50 & 90 & $0.71 \pm 0.05$ & + \\
\hline & 3 & 50 & 38.03 & 37.40 & $60 \sim 90$ & $0.63 \pm 0.35$ & - \\
\hline & 3 & 50 & 38.23 & 37.73 & $60 \sim 150$ & $0.55 \pm 0.09$ & - \\
\hline
\end{tabular}

第 5 表 シロネズミにたいする coumarin-3-carboxylic acid 誘導体の低温時に扣ける 体温降下作用（経口投与）（12～ $14^{\circ} \mathrm{C}$ )

\begin{tabular}{|c|c|c|c|c|c|c|c|}
\hline 化 & $\begin{array}{l}\text { 供 試 } \\
\text { 動物数 }\end{array}$ & $\begin{array}{c}\text { 投与量 } \\
\mathrm{mg} / \mathrm{kg}\end{array}$ & $\begin{array}{c}(\mathrm{a}) \\
\text { 正常体温 }\end{array}$ & $\begin{array}{c}(b) \\
\text { 最低体温 }\end{array}$ & $\begin{array}{l}\text { 到達時間 } \\
\text { (分) }\end{array}$ & $\begin{array}{l}(a-b) \\
\pm S . D\end{array}$ & $\begin{array}{c}(\mathrm{a}-\mathrm{b}) \\
\text { の有意性 } \\
\text { の㭘定 }\end{array}$ \\
\hline $\begin{array}{l}\text { 6-Coumarinylamine coumarin- } \\
\text { 3-carboxylate }\end{array}$ & 3 & 50 & 37.45 & 36.40 & $30 \sim 60$ & $1.05 \pm 0.20$ & $t$ \\
\hline $\begin{array}{l}\text { Thallium coumarin-3-carboxy- } \\
\text { late }\end{array}$ & 3 & 50 & 37.43 & 36.70 & 90 & $0.73 \pm 0.25$ & - \\
\hline Warfarin & 3 & 50 & 37.08 & 36.76 & $30 \sim 120$ & $0.32 \pm 0.06$ & - \\
\hline
\end{tabular}


第 6 表 6-Coumarinylamine coumarin-3-carboxylate の溶血作用（家鬼赤血球浮游液）

\begin{tabular}{|c|c|c|c|c|c|c|c|c|c|}
\hline 化 合物 濃 度 & $\left|\begin{array}{c}5.00 \times \\
10^{-4} \mathrm{~g} / \mathrm{m} l\end{array}\right|$ & $\begin{array}{c}3.00 \times \\
10^{-4}\end{array}$ & $\begin{array}{r}2.00 \times \\
10^{-4}\end{array}$ & $\begin{array}{r}1.00 \times \\
10^{-4}\end{array}$ & $\begin{array}{r}5.00 \times \\
10^{-5}\end{array}$ & $\begin{array}{l}3.00 \times \\
10^{-5}\end{array}$ & $\begin{array}{r}2.50 \times \\
10^{-5}\end{array}$ & $\begin{array}{r}1.50 \times \\
10^{-5}\end{array}$ & $\begin{array}{c}1.00 \times \\
10^{-5}\end{array}$ \\
\hline $\begin{array}{l}\text { 6-Coumarinylamine } \\
\text { coumarin-3-carboxylate }\end{array}$ & H & H & & H & + & \pm & - & & , \\
\hline サ ポ & H & $H$ & H & & + & & & + & \pm \\
\hline
\end{tabular}

第 7 表 6-Coumarinylamine coumarin-3-carboxylate の血液凝固阻止作用 (Quick, 一 段法)

\begin{tabular}{|c|c|c|c|c|c|}
\hline 化 & 合 & 物 & $\stackrel{\substack{\text { 濃 } \\
(\mathrm{g} / \mathrm{m} l)}}{\text { 度 }}$ & 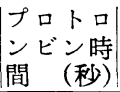 & $\begin{array}{c}\text { 凝固価 } \\
(\%)\end{array}$ \\
\hline 対 & 照 & 区 & 0 & 15 & 100 \\
\hline \multicolumn{3}{|c|}{$\begin{array}{l}\text { 6-Coumarinylamine } \\
\text { coumarin-3- } \\
\text { carboxylate }\end{array}$} & $\begin{array}{l}1.25 \times 10^{-3} \\
2.50 \times 10^{-4}\end{array}$ & $\begin{array}{l}27.7 \\
22.1\end{array}$ & $\begin{array}{l}25 \\
44\end{array}$ \\
\hline \multicolumn{3}{|c|}{ シントローム } & $1.25 \times 10^{-3}$ & 18.2 & 64 \\
\hline
\end{tabular}

ら経時的に採血を行ない，その赤血球数をThoma の 血球計算器で測定したところ, 投与 30 分後に顕著な低 下が認められ，約 5 時間にわたって作用が持続した。

\section{II. 応用試験}

以上主として 6-coumarinylamine coumarin-3carboxylate について, 毒性あるいは殺鼠効果に関係 あると考えられる薬理作用を検討したが，さらにシロネ ズミおよびハツカネズミを用いて, 飼料摂取試験, 飲料 水摂取試験, 殺鼠剂散布試験および殺鼠効果に及ぼすビ タミン $\mathrm{K} の$ 影響試験などを行なった。

飼料摄取試験：アメリカ合衆国において忌避剤選出の ための第一次試験法として採用されている飼料摂取試験 (BELLACK et al., 1953) を行なった。この方法は飼料 に供試検体を混合して試験動物に与えたとき，消費量が どのように变化するかを観察し, 次式により忌避係数 $\mathrm{K}$ を求める。この值が 100 に近いほど忌避性が強いので, 殺鼠剤として応用する場合は K の值が 100 より離れる ほど好ましいわけである。

$$
\begin{gathered}
\mathrm{K}=100-\frac{1}{100 \mathrm{~W}}\left(8 \mathrm{~T}_{1}+4 \mathrm{~T}_{2}+2 \mathrm{~T}_{3}+\mathrm{T}_{4}\right) \times \\
\left(\mathrm{U}_{1}+\mathrm{U}_{2}+2 \mathrm{U}_{3}+4 \mathrm{U}_{4}+8 \mathrm{Y}\right) \\
\mathrm{T}_{1} \cdots \cdots \mathrm{T}_{4}=\text { 試験第 } 1 \cdots \cdots \text { 第 } 4 \text { 日目に攝取され } \\
\text { た検体添加飼料量 }(\mathrm{g}) \\
\mathrm{U}_{1} \cdots \cdots \mathrm{U}_{4}=\text { 試験第 } 1 \cdots \cdots \text { 第 } 4 \text { 日目に摂取され } \\
\text { た対照（検体無添加）飼料量 }(\mathrm{g}) \\
\mathrm{W}=\text { 供試動物の体重 }(\mathrm{g}) \\
\mathrm{Y}=\text { 試験終了日における対照飼料の残存量 }(\mathrm{g})
\end{gathered}
$$

飼料としてはコムギ粉，コメ粉，トウモロコシ粉 (4:
1:1) を水 1.7 容と混合, ねり合わせ，これに 6-coumarinylamine coumarin-3-carboxylate $0.5 \%$, $1.0 \%, 2.0 \%$ の割合で添加し, 厚さ $1.5 \mathrm{~mm}$, 縦横各 $1 \mathrm{~cm}$ の大きさに切断し, 乾燥した。シロネズミは1群 3 頭（体重は 139～161 g ）とし，1 日あたり検体添加 飼料および無添加飼料を各 $60 \mathrm{~g}$ あて与えた。第 1 日か ら第 4 日をでの摂取量から忌避係数Kを求めたところ, $0.5 \%$ 添加区で - 1189.4, 1\% 添加区で $-806.5,2 \%$ 添加区で-500.9 となった。すなわち 6-coumarinylamine coumarin-3-carboxylate の含有濃度が低い程 よく摂取されることは明らかであるが，0.5\% の濃度は 半野生ネズミで調査した結果からは殺鼠剂として応用可 能な濃度である。

饮料水攝取試験：シロネズミ5頭を一群（体重は 128 $\sim 241 \mathrm{~g}$ ) とし, 6-coumarinylamine coumarin-3carboxylate の $0.025 \%, 0.05 \%, 0.1 \%$ 水溶液ある いは正常（無添加）飲料水を与えて 24 時間後の各群の 摂取量を求めた。その結果正常飲料水投与区の飲料水椇 取量 100 に対して，0.025\% 添加区および $0.05 \%$ 添加 区の掑取量は 76 ，また $0.1 \%$ 添加区の捸取量は 62 と なった。すなわち低濃度になるほど㩫取量は多くなるわ けで, 対数確率紙から求めた $50 \%$ 忌避濃度は $0.48 \%$ であった。

殺鼠剈にたいするビタミン $\mathbf{K}$ の影響：従来のクマリ ン系殺鼠剤の特長は血液凝固阻止作用をもつことであ る。したがってクマリン系殺鼠剤を摂取したネズミが， 血液凝固作用をもつビタミン $\mathrm{K}$ を含む食物を摂取する と, 殺鼠効果が減退することが考えられる。ハツカネズ ミ 1 群 5 頭（体重は 15～20 g ）を用いて，とれぞれビ タミン $\mathrm{K}$ 投与群 ( 1 頭あたり $0.1 \mathrm{mg})$, 生キャベツ投与 群（1頭あたり $15 \mathrm{~g}$ 投与; 生キャベッ $15 \mathrm{~g}$ 中にビタる ン $\mathrm{K}$ を約 $0.1 \mathrm{mg}$ 含有する)，ビタミン $\mathrm{K}$ 無投与群にた いして, 6-coumarinylamine coumarin-3-carboxylate あるいはワルフォリンを $50 \mathrm{mg} / \mathrm{kg}$ あて経口投与 し, 死亡状態をしらら゙た。その結果, ワルフォリンはビ タミンKによって効果が若干低下する傾向を示したが， 6-coumarinylamine coumarin-3-carboxylate では 
第 8 表 ハッカネズミにたいする 6-coumarinylamine coumarin-3-carboxylate 招よび thallium coumarin-3-carboxylate の散布試験

\begin{tabular}{|c|c|c|c|c|c|c|c|c|}
\hline 物 & 調査項目 & 第 1 日 & 第 2 日 & 第 3 日 & 第 4 日 & 第 5 日 & 第 6 日 & 第 7 日 \\
\hline $\begin{array}{l}\text { 6-Coumarinylamine } \\
\text { coumarin-3-carboxylate }\end{array}$ & $\begin{array}{l}\text { 死亡 数 } \\
\text { 積算死亡数 } \\
\text { 積算死亡率 }\end{array}$ & $\begin{array}{c}1 \\
1 \\
12.5\end{array}$ & $\begin{array}{c}3 \\
4 \\
50.0\end{array}$ & $\begin{array}{c}0 \\
4 \\
50.0\end{array}$ & $\begin{array}{c}0 \\
4 \\
50.0\end{array}$ & $\begin{array}{c}2 \\
6 \\
75.0\end{array}$ & $\begin{array}{c}1 \\
7 \\
87.5\end{array}$ & $\begin{array}{r}1 \\
8 \\
100\end{array}$ \\
\hline $\begin{array}{l}\text { Thallium coumarin-3- } \\
\text { carboxylate }\end{array}$ & $\begin{array}{l}\text { 死亡 数 } \\
\text { 皘算死亡数 } \\
\text { 積算死亡率 }\end{array}$ & $\begin{array}{c}1 \\
1 \\
12.5\end{array}$ & $\begin{array}{c}0 \\
1 \\
12.5\end{array}$ & $\begin{array}{c}2 \\
3 \\
37.5\end{array}$ & $\begin{array}{c}2 \\
5 \\
62.5\end{array}$ & $\begin{array}{r}3 \\
8 \\
100\end{array}$ & & \\
\hline
\end{tabular}

ビタミンKの影響は認められなかった。

殺鼠郕散布試験：6-Coumarinylamine coumarin3-carboxylate および thallium coumarin-3-carboxylate を面積 $221 \mathrm{~cm}^{2}$ のホーロー引きのバットに 5 $\mathrm{mg} / \mathrm{cm}^{2}$ の割合で均一に散布し, 1 群 8 頭のハッカネ ズミ䒚 1 頭ずつ 1 日 30 分間歩行させ, その後は正常に 飼育した。一般にネズミ類は歩行中に脚, 尾, 腹面など に附着した物質をなめる習性があり（三坂，1944）, こ の際に薬物が経口的に消化管内に取込まれて中毒を起 す。結果注第 8 表のように, 6-coumarinylamine coumarin-3-carboxylate では7 日目に，また thallium coumarin-3-carboxylate では 5 日目に全部死亡した。 したがって野生ネズミの巣の入口，通路などに散布して 殺鼠効果をあげる可能性があるものと考えられる。

$$
\text { 総括 }
$$

著者らは新殺鼠凨開発の一連の研究において, cou- marin-3-carboxylic acidおよびその 6-coumarinyl amine やタリウム塩がすぐれた殺鼠効果をもち，またネ ズミ類にたいする忌避性の少ないことを見いだした。こ れらの化合物は急性毒性, 体温降下作用, 溶血作用およ び血液凝固阻止作用などの諸効果が強く, 一方イヌやネ コにたいしてはほとんど無害で実験的に大量投与しても 欧吐をもよおす程度であった。さらにネズミの致死様式 も自然死と変らない。したがってこれらの化合物は殺鼠 剂として実用化される可能性は十分あると考えられる。

\section{引用 文 献}

Bellack, E. et al. (1953) Chem. Biol. Coordination-Center Review 5.

北川晴雄·岩城利一郎 (1958 a ) 薬学雉誌 78: 491 . 北川晴雄 - 岩城利一郎 (1958b) 薬学雉誌 79: 639 . 三坂和英 (1944) 応動篗 15: 43 .

\section{Summary}

\section{Studies on Coumarin-3-carboxylic Acid and its Derivatives as Rat Poison I. Fundamental Investigations with Rat (Rattus norvegicus var. albinus) and Mouse (Mus musclus)}

\footnotetext{
By Haruo Kitagawa, Riichiro Imaki, Haruo Saito (Faculty of Pharmaceutical Sciences, University of Toyama), Masami Motizuki (Toyama Agricultural Experiment Station), Ryusho Takeda, Toshiharu Suzuki, Masanori Turuga, Naokazu Inazuka and Kiyoshi Ogawa (Fuji Chemical Industries Ltd., Takaoka)
}

According to the previous findings that coumarin-3-carboxylic acid and 6-coumarinylamine coumarin-3-carboxylate have a strong hypothermal action and toxic action to rats, a study was made in an effort to apply these compounds as rat poisons. These compounds and in addition, thallium coumarin-3-carboxylate have superior toxic effect on rat (Rattus norvegicus var. albinus) and mouse (Mus musclus), and have a little toxicity for domestic animals such as dogs and cats. Thus, there may be a possibility of application of these coumarins as rat poisons for practical use. 